\title{
La ciudad herida. Siete ejemplos paradigmáticos de rehabilitación urbana en la segunda mitad del siglo $\mathrm{xx}$
}

Francisco Segado-Vázquez. Universidad Politécnica de Cartagena, Murcia, España. Víctor Manuel Espinosa-Muñoz. Universidad Politécnica de Cartagena, Murcia, España.

RESUMEN | En la historia del urbanismo, la segunda mitad del siglo xx marca un punto de inflexión. Los métodos de desarrollo urbano aplicados hasta la fecha ya no consiguen dar respuesta a los problemas surgidos en el corazón de las ciudades: guetos, inseguridad o delincuencia. Resulta necesario buscar nuevos métodos para la recuperación del pulso vital de nuestros barrios. Kreuzberg en Berlín, el centro histórico de Bolonia, Le Marais en París, Fener y Balat en Estambul, Molenbeek en Bruselas, Mouraria en Lisboa y Lavapiés en Madrid se han convertido en ejemplos paradigmáticos de la nueva idea de rehabilitación urbana. La diversidad social, que evita la creación de guetos; la calidad de los espacios públicos, que favorece las relaciones interpersonales; y la salvaguarda, que mantiene y fortalece la imagen que tenemos de nuestro entorno urbano, se convierten en conceptos necesarios para recuperar nuestra "ciudad herida".

PALABRAS CLAVE | Centros urbanos, espacio público, renovación urbana.

ABSTRACT | The second half of the 20th century marks a point of inflexion in the history of urbanism. The methods of urban development that have been applied thus far are no longer capable of answering some of the central problems embedded in the heart of cities: ghettos, insecurity or criminality. It is necessary to look for new methods capable of generating the recovery of the life force of urban neighborhoods. Kreuzberg in Berlin, the historical center of Bologna, Le Marais in Paris, Fener and Balat in Istanbul, Molenbeek in Brussels, Mouraria in Lisbon and Lavapiés in Madrid have turned into paradigmatic examples of this new idea of urban rehabilitation. Social diversity, which prevents the creation of ghettos; quality public spaces, which favors interpersonal relations; and safety, which supports and strengthens the image that have been built regarding the urban environment, emerge as crucial concepts for the recovery of our "wounded city".

KEYwORDs | urban centres, public space, urban renewal. 


\section{Introducción}

"Arden los guetos". De esta manera tan contundente daba comienzo un artículo publicado en el diario El Pais en diciembre de 2007, cuyo tema versaba sobre la desesperanza que inundaba a grupos de jóvenes residentes en zonas acotadas de la periferia de París desde las revueltas acontecidas dos ańos antes. En 2005, la violencia callejera en algunos barrios de la capital francesa abrió un intenso debate sobre la responsabilidad que les cabía a la arquitectura y el urbanismo de algunos distritos en el desenlace de los continuos enfrentamientos. Escasez de viviendas dignas con un mínimo de prestaciones, falta de transporte público, servicios deficientes e inexistencia de espacios públicos de reunión se contabilizaron como las principales causas de la falta de integración social.

Los programas de rehabilitación urbana desarrollados a lo largo de la segunda mitad del siglo xx en Europa han pretendido servir de guía para solucionar una serie de problemas que solían reiterarse en las ciudades de nuestro entorno. Resulta inevitable la formulación de preguntas tras la observación, estudio y análisis de los programas realizados para solventar tales problemas: ¿han cumplido la función para la que fueron creados? ¿Es posible y factible dar una solución global a los problemas de las grandes ciudades ahora que pertenecemos a una -según acuñó el sociólogo canadiense Marshall McLuhan- "aldea global”? ¿Qué han aprendido nuestros barrios de ellos, con la perspectiva que tenemos en la actualidad, ya en la segunda década del siglo XXI?

Con un marcado carácter premonitorio, Fritz Lang y Thea von Harbou nos presentaron, en 1927, una "distopía" urbana futurista en que disectan la ciudad actual. En su filme Metrópolis, que imagina una gran urbe del siglo xxi, los obreros viven en un gueto subterráneo donde se encuentra el corazón industrial, con la prohibición de salir al mundo exterior.

La disciplina urbanística adquiere una vital importancia dentro de un problema multidisciplinar, respecto del cual hay que tener en cuenta factores tanto sociológicos como económicos y políticos. No se pueden evitar las referencias a las oportunidades políticas de llevar a cabo una determinada intervención urbana o a las posibilidades económicas de una comunidad para realizar el planeamiento urbanístico propuesto, sin pasar por alto las relaciones de los propios habitantes de un barrio, entre sí y con su entorno más inmediato.

Son numerosos los profesionales de diversas disciplinas que han dejado su aportación a las teorías relativas a la rehabilitación urbana, en toda su diversidad. Arquitectos, sociólogos, economistas o antropólogos nos han proporcionado buena muestra de sus investigaciones en constantes publicaciones.

François Ascher, sociólogo urbano, publicó en el año 2001 Les nouveaux principes de l"urbanisme. La fin des villes n"est pas à l"ordre du jour (Los nuevos principios del urbanismo). Se trata de un análisis sobre la "tercera revolución urbana", la que sucede a la ciudad del Renacimiento y a la urbe de la Revolución Industrial. Ascher denomina "neourbanismo" al nuevo urbanismo surgido de las necesidades de una sociedad inmersa en el siglo xxi, para diferenciarlo del "paleourbanismo" de la ciudad clásica y del urbanismo, concepto elaborado tras la Revolución Industrial. 
Desarrolla al respecto diez principios de lo que sería este nuevo urbanismo, los cuales, orientados a dar respuesta a las necesidades urbanas actuales, abordan conceptos como la adaptación a las diferentes necesidades urbanas, los nuevos usos sociales, la readaptación de la misión de los poderes públicos, la promoción de una nueva calidad urbana o la adaptación de la democracia a la tercera Revolución Urbana.

Jane Jacobs, con The death and life of great American cities (Muerte y vida de las grandes ciudades), su obra más influyente, publicada en 1961, realiza una dura crítica a las prácticas de renovación urbana de los años cincuenta en los Estados Unidos. Los modelos teóricos ideales en los que se sustentaban los urbanistas para planear las transformaciones urbanas conllevaban una degradación del espacio público y, por consiguiente, una merma en la calidad de vida de los habitantes de la ciudad. Aunque los fragmentos de ciudad estudiados en el libro estén ubicados en los Estados Unidos, en un mundo globalizado es evidente que trata de problemas extrapolables a cualquier gran ciudad europea.

En el libro de Jacobs nos encontramos con dos temas recurrentes: el tratamiento del espacio público y la diversidad urbana. Dentro del primero se estudian los usos que se realizan de las aceras en diversas calles, en función de la seguridad que ofrecen, el contacto entre los peatones y la incorporación de los nińos. Asimismo se analizan los parques vecinales y su necesidad dentro de un contexto urbano determinado. La diversidad urbana adquiere una vital importancia a la hora de mantener viva una parte de la ciudad y Jacobs establece una serie de condicionantes para que esto ocurra, justificándolo mediante ejemplos reales. Un barrio activo y dinámico debe poseer una cierta combinación de usos primarios, ubicados en manzanas pequeñas que favorezcan las alternativas de tránsito (Figura 1). Los edificios antiguos deben convivir con los modernos en una zona altamente densificada.

FIGURA I | Esquema de alternativas de tránsito

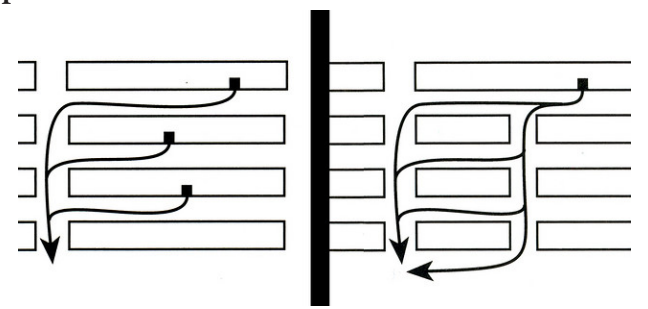

FUENTE J. JACOBS, muerte y vida de las grandes ciudades (I96I), PP. 2 I 2 Y 2 I 3 DE EDICIÓN EN CASTELlano (20I I)

Jaime Lerner, arquitecto, urbanista y político brasileño, publicó en el año 2003 Acupuntura urbana, un libro conformado por una colección de ensayos en los que se reflexiona acerca del fenómeno urbano. "La ciudad no es el problema. La ciudad es la solución” (Serra, 2005, s/p.). Este es el lema del arquitecto que tuvo la oportunidad de poner en práctica parte de sus principios en la ciudad de la que fue alcalde: Curitiba. Otra de sus reflexiones sobre el desarrollo de las ciudades es la siguiente: "Da igual la estructura de la ciudad, lo que hay que tener muy claro es de qué vive la gente y cuáles 
son sus necesidades para vivir y trabajar. Lo más sostenible es no gastar energía yendo de una función a otra, se trata de mezclar usos" (ídem). Esto no quiere decir, según él, que no haya que usar el coche, sino que se debe racionalizar su uso. La mezcla de usos es un concepto importante, tanto para ahorrar energía como para dotar de vida una determinada zona durante un mayor número de horas a lo largo del día.

Richard Rogers, en Cities for a small planet (Ciudades para un pequeño planeta, 2012), reflexiona sobre los tipos de espacios públicos de las ciudades y los beneficios que supone la mezcla de usos y de clases sociales. Clasifica el espacio público en dos grupos diferenciados: cerrado y abierto. El espacio público cerrado sería aquel que desarrolla una única función, como los barrios residenciales, los distritos financieros, las zonas industriales o los aparcamientos. El espacio público abierto es multifuncional, y en él encontraríamos la plaza, la calle concurrida, los mercados, los parques o las terrazas. "La desaparición del espacio público abierto no supone una mera causa de queja, sino que puede ocasionar una degradación social extrema" (p. 10). Mediante esta sentencia advierte del peligro de numerosos planes de planificación y rehabilitación que relegan el espacio público a un mero espacio residual de conexión entre diversas zonas bien diferenciadas entre sí. La retirada de la población hacia los barrios periféricos y el consiguiente incremento de la pobreza en los centros urbanos dañan gravemente la buena salud de nuestros barrios. Es necesario un mayor compromiso individual para con la ciudad y garantizar de este modo un crecimiento sostenible de la misma.

Oriol Bohigas, en Contra la incontinencia urbana. Reconsideración moral de la arquitectura y la ciudad (2004), afirma que contra el planeamiento de bloques "monofuncionales" ha de reafirmarse la defensa de la mezcla de funciones diversas y de distintos tipos de vivienda en un mismo edificio y en un mismo barrio. Asimismo, arremete contra el descontrolado desarrollo de las periferias alentado por operaciones especulativas reflejadas en los diversos planes urbanísticos, lo que acaba provocando un empobrecimiento del centro tradicional de la ciudad. Ante esta expansión desbocada y sin límites se puede luchar mediante la "reconstrucción" de la ciudad consolidada: rehabilitar, compactar, reutilizar lo construido para funciones nuevas o complementarias. La plurifuncionalidad y la compacidad solo tendrán éxito si se articulan bien los espacios públicos: la calle, la plaza, el parque, o los edificios representativos.

El arquitecto argentino Luis J. Grossman, en su columna del diario La Nación, "Arquitextos", realiza un alegato a favor de la "vuelta al barrio". En él advierte del problema ocasionado por la pérdida de identidad de los barrios y la urgente recuperación por parte de sus residentes del sentido de pertenencia a su espacio más próximo. Gildo Seisdedos, en Cómo gestionar las ciudades del siglo xxi (2007), dice del centro urbano de muchas de nuestras ciudades que "su bello cadáver es embalsamado con técnicas de conservación". Su belleza atrae al turismo, pero carece de servicios urbanos, los que se ofrecen a precios prohibitivos, tendencia favorecida por la gentrificación.

El antropólogo francés Marc Augé, en su libro Los no lugares, espacios del anonimato (2003), acuña un nuevo término para definir todos aquellos espacios urbanos actuales caracterizados por no proporcionar un ámbito de relación personal entre los habitantes de la ciudad: el "no lugar". Las estaciones de transporte de viajeros, 
los hoteles, los supermercados pasarían a formar parte de esta clasificación. Lo inquietante es que los espacios públicos de las ciudades, esos que históricamente sustentaban las relaciones entre sus habitantes, se han convertido en "no lugares". En muchas ciudades, las calles de los centros urbanos se han convertido en meros sitios de paso, en autopistas urbanas peatonales que hay que atravesar cuanto antes para llegar a nuestro destino.

Kevin Lynch, en The image of the city (La imagen de la ciudad, 1960), define el término barrio, district, enfatizando los caracteres que lo hacen único y que le sirven de referencia, tanto interna como externa. Ese carácter común, esa esencia que identificó y caracterizó una determinada zona de una ciudad, ese vínculo que proporcionó a sus habitantes un fuerte lazo de unión, se debe intentar recuperar a la hora de rehabilitar una zona degradada. Se trata de recobrar la antigua "imagen" de un barrio que fue amable, ahora dañada y deteriorada, y no solo para sus habitantes, sino también para todos los que forman parte de la ciudad.

Sin embargo, ese concepto de "imagen" al que alude Lynch puede llegar a convertirse, según afirma el geógrafo Francesc Muñoz en su libro Urbanalización (2008, p. 67) en uno de los "cuatro requerimientos cuya presencia, en dosis diferentes, mantiene y alimenta el proceso de urbanalización". Muñoz define la "urbanalización" partiendo de tres procesos: la "especialización económica y funcional, que reduce la diversidad de actividades", la "segregación morfológica del espacio urbano" y la "tematización del paisaje de la ciudad". Se vuelve a insistir, mediante este concepto, en la necesidad de recuperar la diversidad urbana, tanto funcional como morfológica.

FIGURA 2 | Manera tradicional de "solucionar" los problemas de degradación urbana
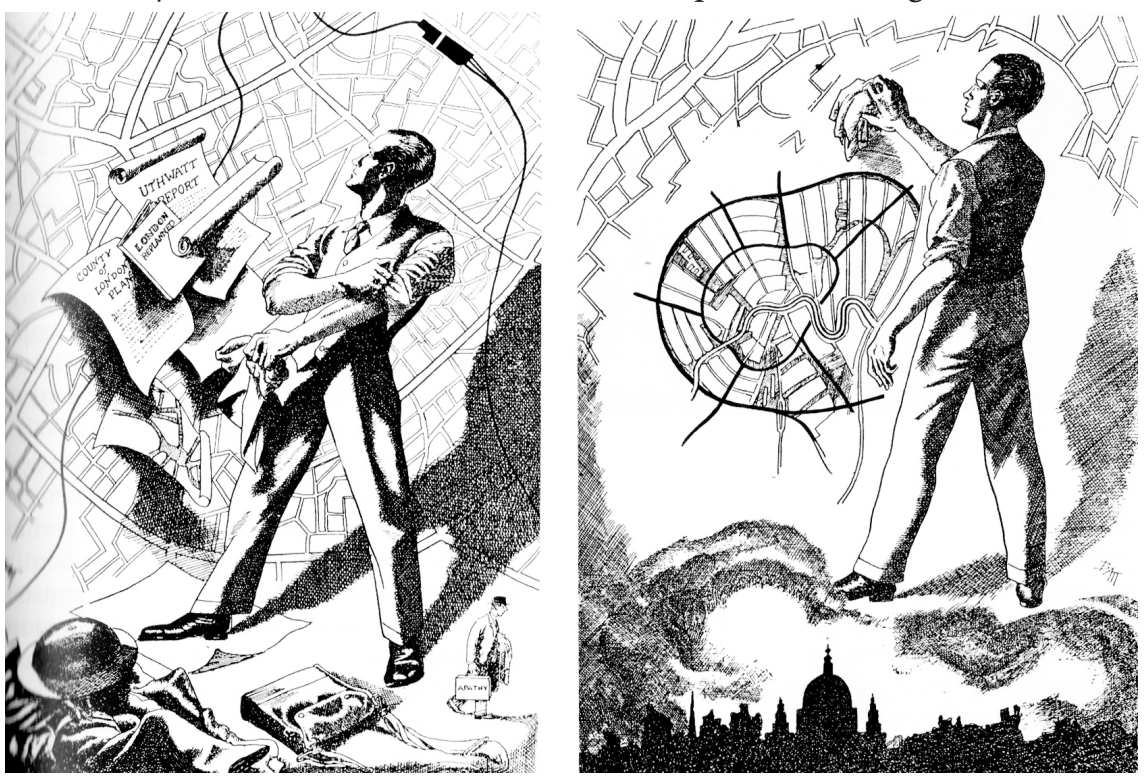

FUENTE

L. BENEVOLO, historia de la arquitectura moderna (I 960), P. 8 I 3 
Charles Benjamin Purdom, de una manera gráfica y esquemática, y con un ligero pero intenso toque de humor, expone el modo de proceder de numerosas administraciones públicas a la hora de enfrentarse ante un problema de rehabilitación urbana (Figura 2). El responsable urbanístico, frente al plano de la ciudad y ante la degradación evidente de una buena parte de la misma, se prepara para entrar en acción, remangándose la camisa. La decisión que ha tomado ha sido borrar literalmente aquellas zonas que no le gustan, o que le molestan, o que presentan muchas complicaciones. Y todo ello lo realiza elevado sobre el perfil de la ciudad, evidenciando su posición de superioridad (véase Benevolo, 1960, p. 813).

La presente introducción se ha configurado como un marco teórico que, a través de diversas definiciones y estrategias descritas por autores notables, pretende ser utilizado como fuente de evaluación de siete ejemplos paradigmáticos de rehabilitación urbana en Europa.

\section{Siete ejemplos paradigmáticos de rehabilitación urbana}

En la segunda mitad del pasado siglo xx encontramos una serie de ejemplos paradigmáticos de planes de rehabilitación urbana. En todos los casos se ha procurado mantener la esencia característica del barrio frente a otros postulados que abogaban por una transformación radical del mismo. Entre todos ellos, podríamos destacar los siguientes: Kreuzberg en Berlín, el Centro Histórico de Bolonia, Le Marais en París, Fener y Balat en Estambul, Molenbeek en Bruselas, Mouraria en Lisboa y Lavapiés en Madrid.

\section{Kreuzberg. Berlín El barrio}

Kreuzberg fue concebido en 1841 como un barrio de clase media con edificios de dos plantas, talleres y jardines traseros, siguiendo una planificación de Peter Joseph Lenné, coetáneo de Schinkel. Su nombre deriva de la colina del mismo nombre, que en la actualidad se encuentra en el Victoriapark. A finales del siglo xIx, Kreuzberg experimentó una explosión demográfica debida a la industrialización de la ciudad. Sus habitantes eran casi en su totalidad obreros. Se produjo una compactación de la edificación y un aumento considerable de la edificabilidad en contra de los espacios libres existentes, lo cual impidió la ampliación de las instalaciones y las infraestructuras necesarias para dar servicio al aumento de la población.

El urbanista alemán Werner Hegemann denominó a Kreuzberg, a comienzos del siglo xx, "una de las más grandes casas de vecindad del mundo" (Forßmann, 1990, p. 69). En aquel momento, tal y como sucedía también en otros lugares de Europa, los propietarios de los inmuebles debían pagar impuestos en razón del ancho del frente de fachada, y no de la superficie construida total del edificio. Esto provocó que muchos promotores construyeran sus edificios "en profundidad". Una fachada estrecha daba paso, en planta, a más de una vivienda ventiladas por sucesivos patios interiores, excepto la primera, que lo estaba a través de ventanas exteriores a la calle.

La Segunda Guerra Mundial solo destruyó algunas casas singulares, a la vez que dejó una profunda huella en las fachadas de innumerables edificios. Tras la 
construcción del Muro de Berlín, en 1961, la zona del barrio Kreuzberg quedó situada en un límite de la ciudad, cortadas sus comunicaciones tradicionales con un centro urbano que, a partir de ese momento, pasaba a formar parte de Berlín Oriental. Pero, tal y como dijo el arquitecto urbanista Jörg Forßmann (1990): “Lo que la guerra, es decir, los bombardeos y la lucha casa por casa y especialmente la división de la ciudad por el muro, no logró hacer, fue realizado por una planificación inhumana” (p. 71).

La zona oriental del barrio, conocida como SO 36 por su antiguo código postal, quedó prácticamente incomunicada con el centro a raíz de la construcción del muro. Un proyecto de dos autopistas que atravesaban la zona, junto con la planificación de nuevas áreas industriales y rascacielos-viviendas sobre un barrio que previamente debía ser derrumbado por el nuevo interés económico, provocó el abandono de los edificios existentes, emigración hacia otros lugares de la ciudad y una profunda degradación urbana. Esta situación fue aprovechada por diversos grupos, como los inmigrantes turcos y artistas bohemios, para convertirse en los nuevos habitantes del barrio.

En 1979, el proceso de saneamiento llevado a cabo hasta la fecha, consistente en compra de edificios, desalojo, destrucción y nueva construcción, provocó el derrumbe de 7.200 viviendas, un $45 \%$ de la superficie construida. Entre 1970 y 1984, el número de empresas dentro de la zona de actuación de la Exposición Internacional de Arquitectura (IBA: Internationale Bauausstellung), se redujo de 1.060 a 495, mientras que los trabajadores pasaron de casi 20.000 a 11.000 . Entre 1970 y 1979, el número de comercios descendió de 444 a 280. En 1981 se tomó conciencia de que, en su mayoría, los vecinos no deseaban derrumbar sus edificios para construir inmuebles nuevos, sino que querían mantener las viviendas que ya habitaban para mejorar su habitabilidad.

\section{El plan}

El centro como lugar de residencia - Rescatar la ciudad estropeada. Este fue el tema central de la Exposición Internacional de Arquitectura entre 1984 y 1987. La exposición pretendía dotar a la ciudad de Berlín de un instrumento de planificación y gestión cuyo objetivo residiera en la rehabilitación de un trozo de ciudad. El nuevo modelo de planificación urbana debía mostrar con hechos que aún era posible humanizar una zona deprimida. Hardt Walterr Hämer (1985), director del equipo de profesionales de la Alt iвA (IвA Antigua) en Kreuzberg, afirmaba: "mientras Taut construía la colonia de la herradura, el viejo barrio de Kreuzberg siguió hacinándose más y más. Las Siedlungen, en realidad, no eran alternativas” (p. 70).

"Con una vivienda mala, se puede asesinar a sus habitantes, (...) una planificación perfecta según ideales abstractos puede destruir un barrio más que la guerra; (...) con la finalidad de crear un orden sin alma, se expulsa desconsideradamente a habitantes de su barrio" (p. 67). Con estas duras sentencias, Jörg Forßmann, en una ponencia publicada en 1990, expresaba su sentimiento de impotencia al constatar cómo se había producido, en la década de los setenta, la degradación de Kreuzberg. Las protestas de los nuevos habitantes del barrio, junto con ocupaciones ilegales de edificios vacíos, provocaron que la IBA centrara sus esfuerzos en una renovación que fue denominada "cautelosa" debido a la manera como se tenían que ejecutar las políticas de cambio. 
En 1983, el parlamento regional de Berlín aprobó los doce principios de "renovación cautelosa” de Kreuzberg: conservación de los edificios, planificación técnica y social, confianza y seguridad, reorganización de las plantas de las viviendas, renovación por etapas, intervenciones puntuales, modernización de los servicios públicos, derechos materiales y de participación, decisiones de renovación públicas, garantías financieras, separación de labores de ejecución y gestión y asegurar el futuro.

Los vecinos que, en su gran mayoría, no querían emigrar del barrio, solicitaron una serie de mejoras en sus viviendas, como la inclusión de los baños en el interior de las mismas o el aislamiento de las ventanas. Una coordinadora de afectados, apoyada por IBA, se convirtió en el centro de la resistencia contra el derribo de los edificios, consiguiendo la integración de diversos equipamientos en edificios nuevos y en otros ya existentes (Figura 3).

FIGURA 3 | Plano de renovación y modernización de edificios en Kreuzberg

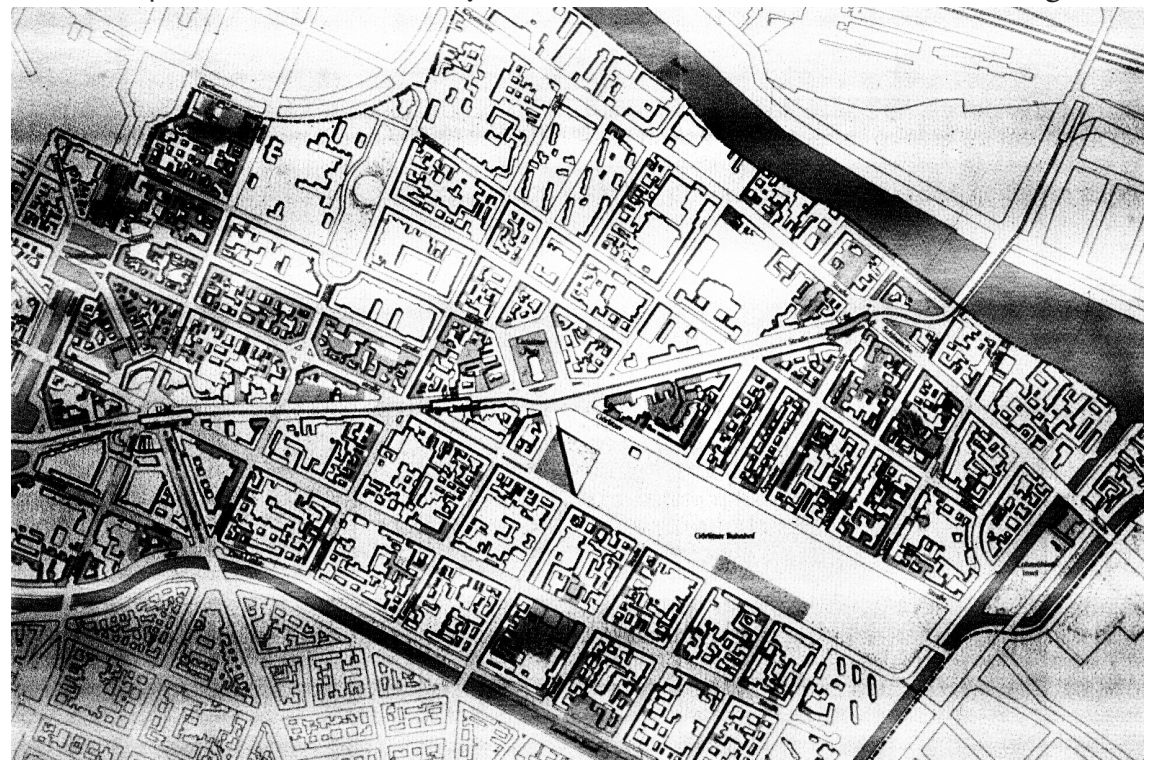

FUENTE J. FORßMANN, ciudad y territorio, 85(3), I990, P. 74

\section{El resultado}

En 1990, tras nueve años de renovación cautelosa, 5.000 viviendas fueron renovadas en edificios antiguos y se construyeron 360 nuevas. Los alquileres de las viviendas en edificios antiguos se mantuvieron en un nivel asequible. En cuanto a los espacios libres, más de 300 patios interiores fueron ajardinados y más de 30 calles y plazas quedaron reestructuradas. Por otro lado, el comercio del barrio se estabilizó con talleres y salas de producción antiguas a las que se ańadieron empresas nuevas.

Con la aplicación de la "renovación cautelosa" se produjo lo que hasta la fecha se pensaba imposible: una estabilización y revitalización del barrio. Los alquileres bajos, el aprovechamiento de los recursos existentes y la unión entre la planificación técnica y social dieron esperanza y confianza en el futuro. 
En la actualidad, y tras una inspección visual, se pueden observar en sus calles tiendas de comestibles y restaurantes turcos conviviendo con tiendas y clubes de clientela berlinesa. Tras las fachadas, algunas renovadas, otras dejando ver el paso de la historia, se esconden los patios interiores; unos arreglados, otros conservando la instalación de talleres y pequeñas empresas. En las siguientes imágenes (Figura 4) se muestra un ejemplo de la evolución del barrio.

FIGURA 4 Kreuzberg

Antes de la rehabilitación del barrio

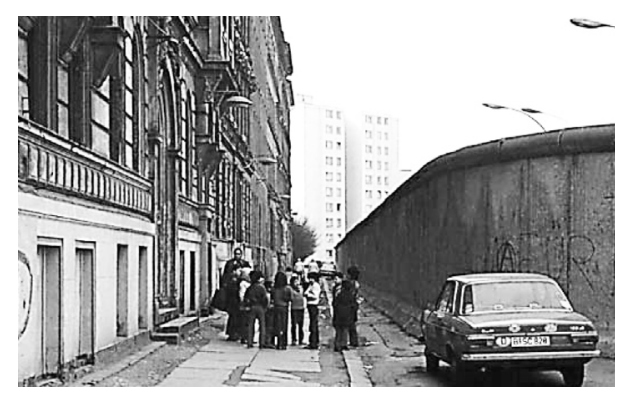

Tras la rehabilitación del barrio

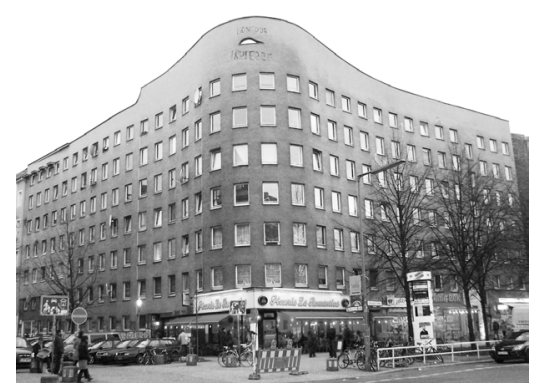

FUENTE URBED/TEN GROUP, learning from fotografía de matías caballero cortés

berlin (2008), P. I9

\section{Centro histórico. Bolonia}

\section{El barrio}

El centro histórico de Bolonia sufrió un progresivo abandono desde la década de los cincuenta del pasado siglo xx, pasando de 113.000 habitantes en 1951 a 80.000 habitantes en 1971. La tasa de edificios sin ocupación alcanzaba el 10\%. La ciudad había crecido de forma dispersa, abandonando el centro para extenderse como una mancha de aceite por la periferia.

La primera aportación fundamental de orden teórico y práctico para la conservación de la ciudad antigua a través de un nuevo método de planificación urbana se la debemos a Bolonia. En 1969, con P. L. Cervellati como asesor de la construcción pública, se redactó un nuevo plan para el centro histórico. Hasta ese momento, y como ocurría en otros ejemplos de rehabilitación de barrios degradados de diversas ciudades, Bolonia tenía un plan urbanístico que pretendía conseguir la renovación urbana a base de demoler y reconstruir, aislando en algunos casos los monumentos de su contexto urbano y ampliando el viario en los distritos medievales para favorecer el paso de los transportes privados. La presión popular, sustentada por las fuerzas culturales existentes en la ciudad en la década de los sesenta, tuvo un gran éxito y provocó que, por primera vez, la conservación tuviera prioridad absoluta ante otras medidas de renovación urbana.

Nació la noción de "centro histórico" como monumento unitario y se le dio una gran importancia a la historia de la ciudad, como ejercicio analítico necesario para determinar qué elementos urbanos podían eliminarse y cuáles eran fundamentales para la conservación del espíritu de la ciudad. Por vez primera se usaron los planos 
catastrales de la época y los planos de construcción originales, que permitieron conocer las técnicas constructivas y las formas de ocupación de los edificios.

\section{Elplan}

A raíz del estudio realizado, se procedió a la definición de cuatro grandes categorías de edificios (Figura 5). En primer lugar se catalogaron los grandes monumentos: palacios, conventos, iglesias, pórticos, etcétera. A continuación, las construcciones con patio y edificios de los siglos XVI y XVII, generalmente rodeadas de pórticos y con jardines. En tercer lugar, las casas de los artesanos y de los obreros, que reflejaban las parcelaciones desde el siglo XIII hasta el XVIII. Por último, todas las edificaciones privadas que surgieron mediante la modificación de las dos categorías precedentes: construcciones con patio y casas de artesanos, o que no se adaptaron a ninguno de los modelos tradicionales.

\section{FIGURA 5 | Bolonia, 1969. Categorías de edificios históricos}
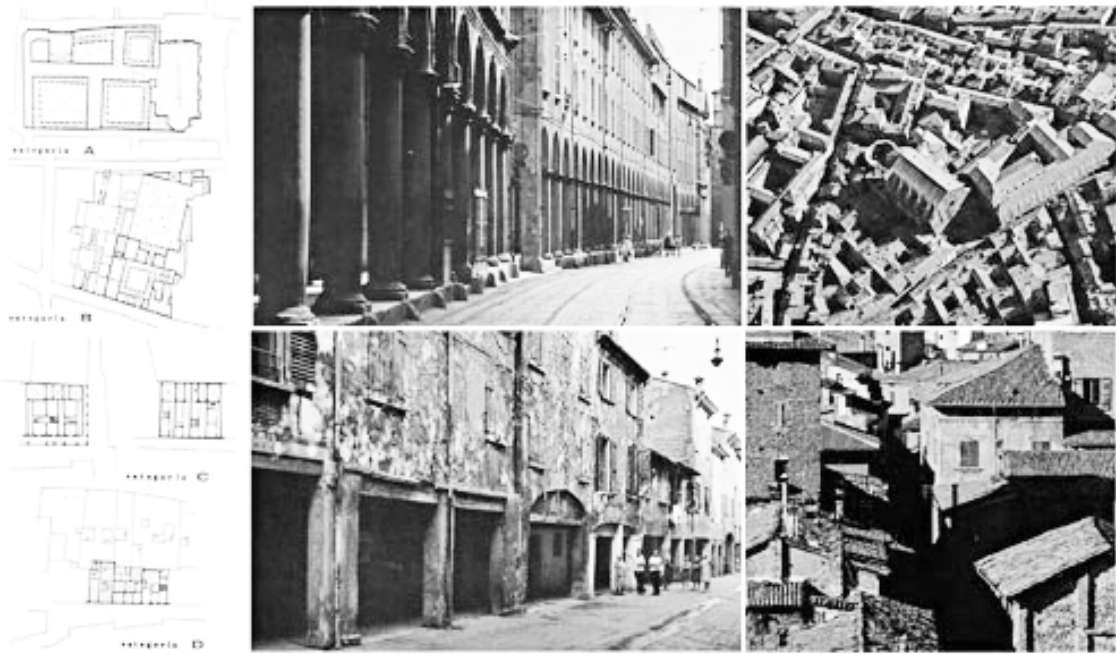

FUENTE LUISA BRAVO, area conservation as socialist standard-bearer: a plan for the historical centre of bologna in 1969 (2009), P. 50

Las intervenciones se fijaron basándose en la historicidad de los edificios y en su grado de integración. Para los futuros usos de las edificaciones se tuvo en cuenta su compatibilidad tipológica. Las actividades colectivas urbanas se instalaron en la primera categoría. Las funciones representativas y culturales en la segunda; las residencias de estudiantes, turistas y ancianos, en la tercera; y todos los demás tipos de residencia, en la cuarta. Las previsiones de las intervenciones consistieron en la restauración de los edificios históricos, la rehabilitación de los espacios interiores libres, la demolición de los cuerpos de fábrica impropios, la utilización de las plantas bajas para actividades comerciales y servicios colectivos y, por último, el restablecimiento tipológico de las construcciones derribadas durante la guerra. 


\section{El resultado}

En la actualidad, las zonas degradadas del centro histórico de Bolonia están saneadas. La reconversión del sector terciario descentralizado a usos residenciales ha provocado un aumento de la población residente. Los supermercados de más de 500 metros cuadrados y las oficinas con gran afluencia de público han sido desplazados por el comercio tradicional especializado de alta calidad. La recuperación del centro urbano de Bolonia ha representado durante mucho tiempo un objetivo importante en los debates de renovación urbana de los centros históricos de numerosas ciudades. En las siguientes imágenes (Figura 6) se muestra un ejemplo de la evolución del barrio.

FIgURA 6 | Bolonia

Antes de la rehabilitación del barrio

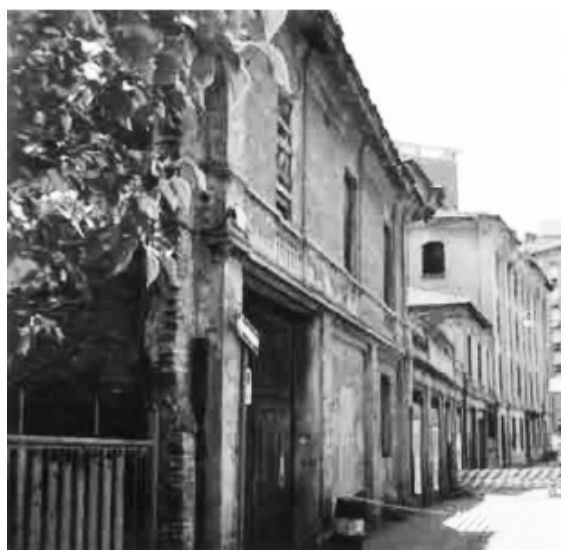

Tras la rehabilitación del barrio

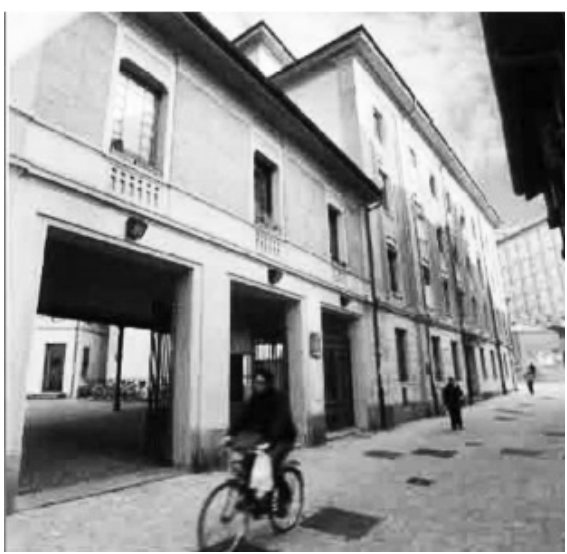

FUENTE SÁNCHEZ, C. (2OIO). EL INEVITABLE PEAJE DE TRANSFORMAR UN BARRIO DEGRADAdo EN UN BARRIO DE MODA..., urbanismo en serie, $\mathrm{s} / \mathrm{P}$

\section{Le Marais. París}

\section{El barrio}

Una amplia marisma existente entre el cauce del Sena y un brazo norte del río actualmente desaparecido, tierra inundable y apta para los cultivos, dio el nombre al barrio parisino de Le Marais. Numerosas comunidades de artesanos, comerciantes y religiosos se instalaron para sacarle el máximo provecho a la fertilidad de las tierras. El siglo XVI confirma su carácter aristocrático, gracias a la construcción de mansiones proyectadas por grandes arquitectos de la época.

En el siglo XviII comienza la decadencia de Le Marais; los más ricos se van desplazando hacia otros sectores de la ciudad, mientras que en el barrio permanecen la pequeña nobleza y las grandes familias arruinadas. La degradación arquitectónica y urbanística no tardará en dar muestras visibles: los patios y jardines de otras épocas se reducen, el interior de las manzanas se ve invadido por nuevas construcciones, los solares se parcelan y los edificios se mutilan. El siglo XIX, con la Revolución Industrial, convierte a Le Marais en una barriada obrera, un enorme taller en el 
que naves y almacenes invaden los jardines y espacios libres que habían resistido los embates de siglos pasados.

Los planes de Haussmann no llegaron a alterar la configuración urbanística de una zona que se fue transformando en uno de los barrios más viejos e insalubres de París. En 1941, el grado de deterioro de determinadas manzanas llevó al ayuntamiento a considerar la posibilidad de arrasar con todo el barrio, exceptuando los contados edificios declarados de interés público. Esta posibilidad provocó el rechazo, por parte de la población, a la destrucción sistemática de las manzanas del barrio, lo que generó un nuevo elemento dentro de la evolución de la política de regeneración de la zona: la salvaguarda.

La opinión pública se fue posicionando cada vez más a favor de la conservación y puesta en valor del entorno. En 1962 se creó una asociación para la Salvaguarda y puesta en valor del París Histórico. La ley Malraux aportó las bases jurídicas, inexistentes hasta la fecha, para la conservación de barrios antiguos en su totalidad. En ese momento se consiguió considerar la salvaguarda como aplicable a todo el entorno del barrio. Los jardines y espacios verdes del interior de las manzanas fueron recuperados. El plan de salvaguarda debía tener como misión adaptar el barrio a las nuevas necesidades sociales, sin la pérdida de su identidad.

El primer proyecto del plan de salvaguarda y puesta en valor de Le Marais, en 1969, ofrece una de las primeras imágenes globales definitorias del futuro del barrio. La agencia de Le Marais fue instaurada como vigilancia para su cumplimiento. Se creó un inventario completo de las edificaciones interesantes, tanto por su calidad arquitectónica como por su contribución al barrio. El plan debía "conservar el equilibrio humano, social y económico del barrio, que se estableciera, para cada acción un plan de realojamiento" (Roca Caldera, 1995, p. 173).

\section{Elplan}

El nuevo plan de renovación del barrio, de 1976, se basaba en tres ámbitos: demolición-limpieza de patios interiores, protección del patrimonio arquitectónico y normas de construcción.

La creación de jardines interiores en los patios de manzana se pospuso, para no alterar el curso de las actividades económicas existentes. Para ello se dictó una norma por la cual una instalación en proyecto de demolición podría seguir en pie siempre y cuando se justificara la continuidad del ejercicio industrial, artesanal o comercial que albergaba.

Los edificios se catalogaron según su nivel de protección: inmuebles protegidos según la legislación de monumentos históricos; inmuebles para conservar en razón de su interés arquitectónico (anteriores al siglo xIx, sobre todo); inmuebles cuya demolición se podrá exigir para alguna operación de ordenación (demoliciónlimpieza de interior de manzana); inmuebles cuya demolición se podrá imponer cuando cese su actividad industrial, artesanal o comercial; e inmuebles sin interés particular que pueden mejorarse o reemplazarse (edificaciones hacinadas del XIX). Las indicaciones para la ejecución del plan fueron, por una parte, la eliminación de añadidos en altura y modificaciones en las edificaciones, a fin de recuperar la 
tipología de origen; y por otra, la mejora de la circulación por calles estrechas y las aperturas visuales mediante la elaboración de pórticos.

Las normas aplicables en los nuevos edificios erigidos en los escasos solares disponibles se modificaron. Las órdenes de retranqueo se abolieron y la altura máxima general se estableció en 25 metros. El volumen global de las construcciones vino determinado por una vertical con un semicírculo en lo alto. Las densidades de ocupación de las construcciones tuvieron diversos coeficientes, dependiendo de su uso como viviendas, comercios, equipamientos, oficinas o servicios públicos (Figura 7).

\section{FIgUra 7 | Plan de Salvaguarda de Le Marais}

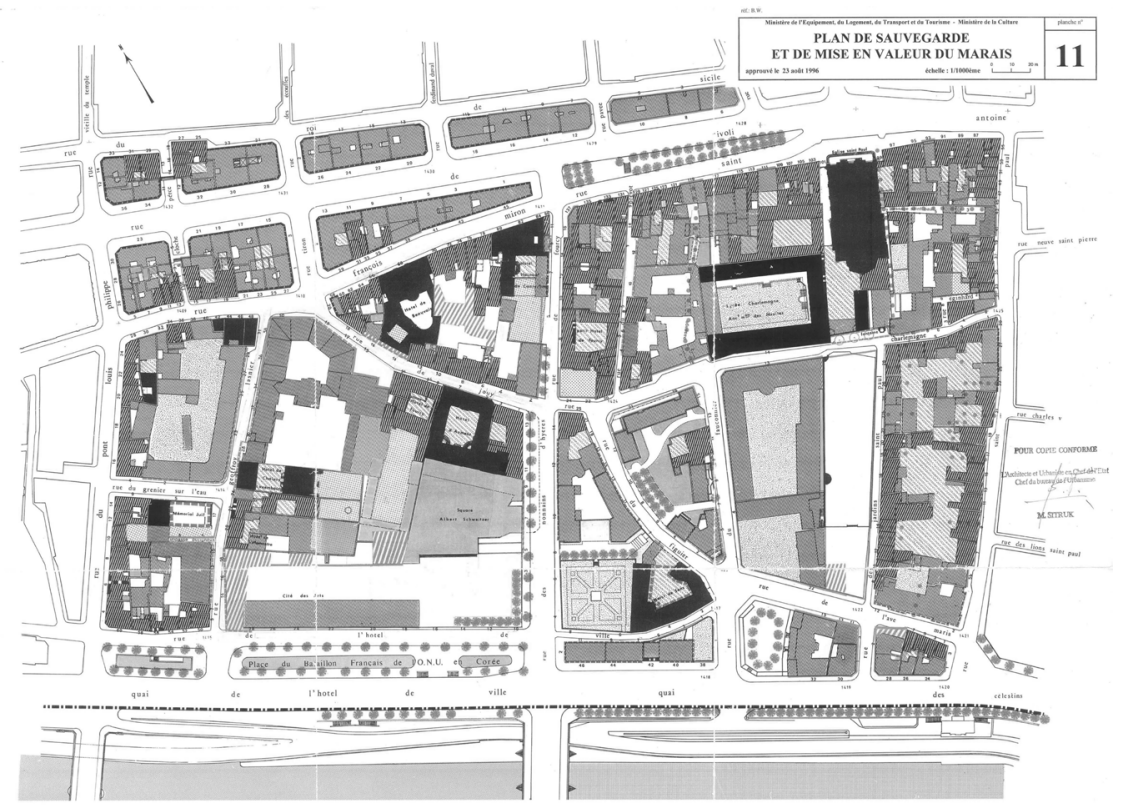

FUENTE HTTP://WWW.PARIS.FR/ACCUEIL/URBANISME/LE-PLAN-DE-SAUVEGARDE-ET-DE-MISE-ENVALEUR-DU-MARAIS-P-S-M-V/RUB_9650_DOSSIER_78334_PORT_23750

\section{El resultado}

La profunda transformación que ha experimentado Le Marais se muestra con total claridad al adentrarse en sus calles, donde se constata la recuperación de las fachadas y la rehabilitación de sus edificios. El barrio se ha convertido en uno de los principales polos de atracción turística de la ciudad de París. Lamentablemente, la reducción de la población, debida principalmente a la política de mejora de las viviendas con la expulsión de las clases sociales más modestas, ha ido acompañada por un detrimento en el número de artesanos, comerciantes e industriales, con larga tradición en la zona. En las siguientes imágenes (Figura 8) se muestra un ejemplo de su evolución. 
FIGURA 8 | Le Marais

Antes de la rehabilitación del barrio

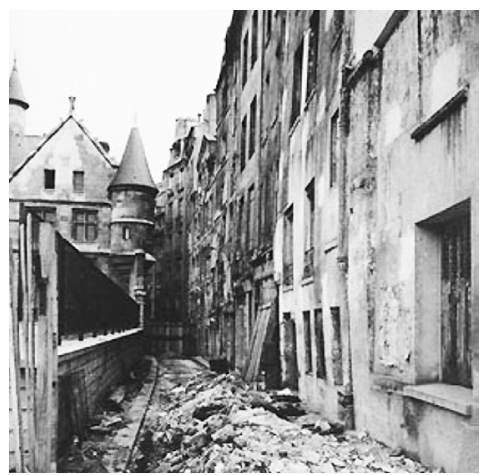

FUENTE paris marais, LE MARAIS EN I960, HTTP://WWW.PARISMARAIS. $\mathrm{COM} / \mathrm{FR} / \mathrm{DECOUVREZ-LE-MARAIS/}$ HISTOIRE-DU-MARAIS/LE-MARAISEN-I 960.НTM
Tras la rehabilitación del barrio

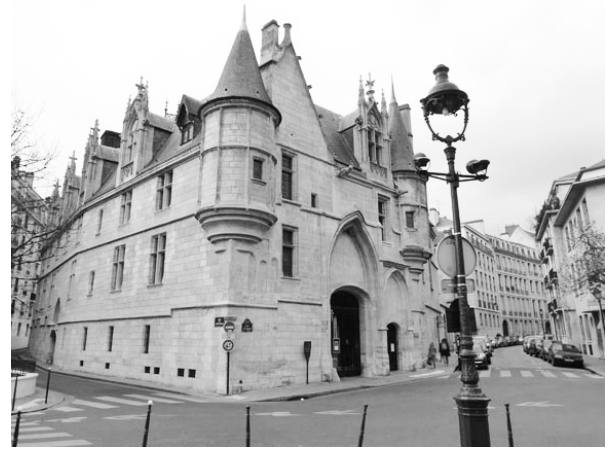

Fuente HTTP://WWW.UNJOURDEPLUSAPARIS.

/PARIS-INSOLITE/HOTEL-DE-SEN

\section{Fener y Balat. Estambul}

\section{El barrio}

En 1968, un grupo de arquitectos realizó una investigación de una zona de la ciudad de Estambul que incluía los barrios de Fener, Balat, Zeyrek y Ayvansaray. Como resultado de la investigación, llegaron a la conclusión de que la totalidad de la zona estudiada había degenerado en un entorno absolutamente degradado. En 1975, la zona de Zeyrek fue la primera en incluirse dentro de un área de conservación.

Después de 1975, y durante un período de veinte años, no se llevó a cabo ningún cambio en el área. La mezquita Molla Zeyrek (antigua iglesia del Pantocrátor, Pantakrato Kilisesi), con más de mil quinientos años de historia, continuaba su degradación. Las fuentes otomanas se habían secado. Los baños históricos estaban en ruinas. Algunas konaks (casas históricas) conservaban la huella de numerosos incendios, mientras las demolidas se iban sustituyendo por estructuras más modernas. Los patios de las mezquitas, de casi quinientos años de historia, se habían convertido en lugares molestos. Las calles adoquinadas habían desaparecido bajo numerosas capas de asfalto. Esta misma situación se daba en los barrios de Fener y Balat.

\section{Elplan}

En 1983, la UNESCo inició una campaña internacional en pro de la salvaguardia de los barrios de importancia histórica de Estambul. El proyecto de rehabilitación de los distritos urbanos Fener y Balat comenzó en el mes de septiembre de 1997, impulsado por la misma unEsco, el instituto francés de investigaciones de Anatolia y voluntarios de Fener.

Dos iniciativas locales, Fener Volunteers Charity y Balat Beautification Charity, se establecieron antes del comienzo del proyecto. Los voluntarios de Fener estaban trabajando en la formación del instituto de investigación Institute of Fener-Balat 
Researches y acogieron a todo el equipo de la unEsco durante el estudio de viabilidad del proyecto. El director del instituto francés de investigaciones de Anatolia, Stefanos Yerasimos, explicaba así el objeto del proyecto: "El proyecto de rehabilitación y restauración se ha realizado para incrementar la calidad de vida de los habitantes de la zona”. Otros ejemplos de restauración y rehabilitación llevados a cabo en la ciudad de Estambul se discutieron en las reuniones.

En el proyecto de la zona de Sogukcesme, las viviendas fueron compradas y los habitantes fueron obligados a marcharse hacia otras zonas de la ciudad. El hecho de que la red social fuera tan importante como las estructuras de los edificios fue completamente ignorado. La calle fue decorada como una escena teatral y se abrió al turismo. En cambio, en el proyecto Kariye la organización emprendió la restauración de las fachadas alrededor del museo Kariye. Los habitantes no tuvieron que desplazarse y la red social se conservó.

Tras la discusión y el estudio de los dos proyectos mencionados, todas las partes interesadas en el proyecto de Fener-Balat acordaron la restauración física del distrito, manteniendo la red social. Las prioridades del proyecto, según el coordinador principal, Remi Stoquart, eran buscar financiación para el desarrollo de viviendas sociales, conservar la estructura histórica del barrio y, por último, adaptar los servicios públicos de acuerdo con las necesidades actuales. El comité finalizó el estudio de viabilidad el 31 de enero de 1998, y el 1 de enero de 2000 comenzó el estudio del proyecto. Debido a la falta de especialistas en el campo de la construcción, se creó una escuela de restauración en el área, asumida por la Universidad Técnica de Berlín. El propósito de la escuela fue dar una formación técnica suficiente y necesaria sobre dibujo y materiales a los estudiantes, para luego poder contratarlos a lo largo del desarrollo del proyecto.

Se creó una "House of Inhabitants" para informar a los residentes de los cambios que se realizarían en su medio más cercano. Se adoptaron políticas de provisión de créditos para la rehabilitación. Se crearon centros educacionales, de reinserción de drogodependientes y zonas deportivas y de juegos para niños. El proyecto también incluía la pavimentación y asfalto de todas las calles del distrito, la conexión con el sistema de gas y la modernización del alcantarillado, y la concienciación pública mediante campańas de planificación familiar y vacunaciones infantiles.

\section{El resultado}

Hasta el mes de junio de 2008, 84 viviendas habían sido restauradas; 27 con una restauración profunda y 57 mediante reparaciones básicas. La reforma de dos edificios para centro social de actividades y de 33 mercados completa las actuaciones de las fases dos y tres del programa de rehabilitación. En las siguientes imágenes (Figura 9) se muestra un ejemplo de la evolución del barrio. 
FIGURA 9 Fener y Balat

Antes de la rehabilitación del barrio

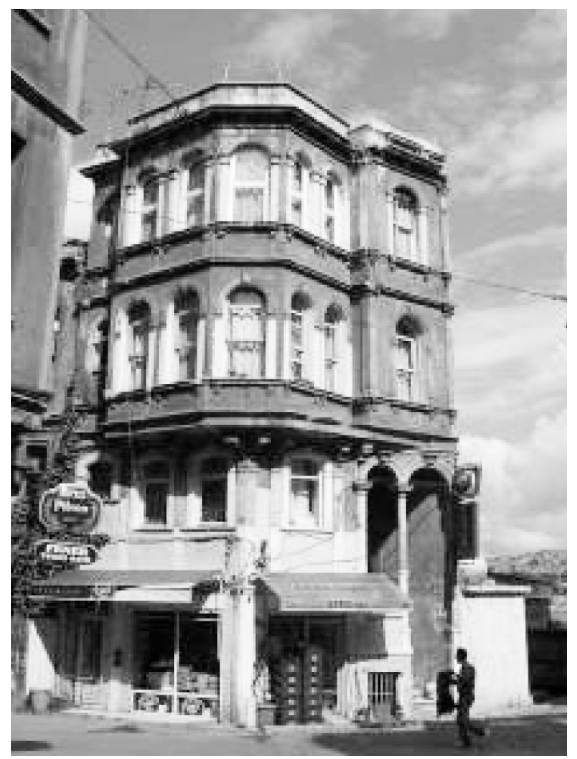

Tras la rehabilitación del barrio

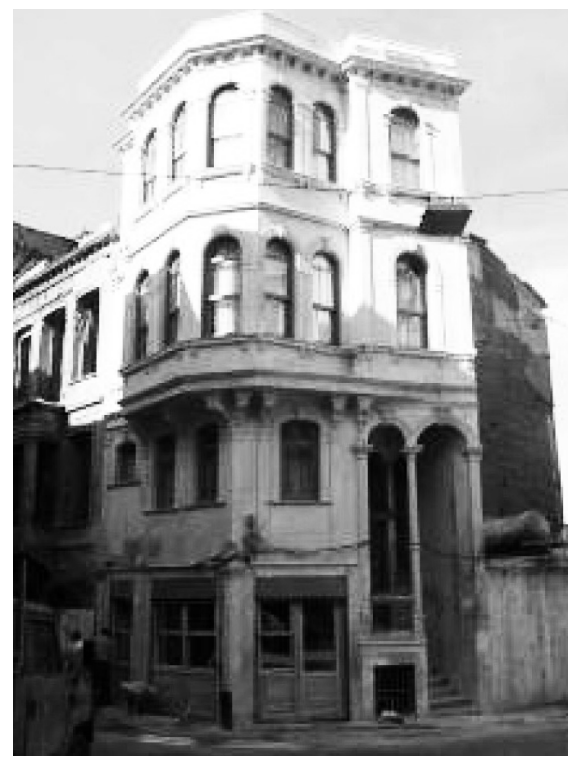

FUENTE M. TUNCER, “FROM KREUZBERG TO FENER-BALAT”, 42nd isocarp congress 2006, P. 7

\section{Molenbeek. Bruselas \\ El barrio}

En 1977, las obras del metro de Bruselas dejaron al descubierto en el distrito de Molenbeek una franja de demolición de un kilómetro de largo que afectó a más de quince manzanas, quedando olvidada durante quince años, hasta 1992. Durante ese tiempo no hubo ningún plan de reacondicionamiento, lo cual causó innumerables daños sociales y económicos al barrio. Las obras del metro de Bruselas, realizadas mediante la técnica de zanja abierta, no llegaron a tener en cuenta las exigencias de reacondicionamiento de la superficie una vez concluidas las intervenciones. Las consecuencias sociales, económicas y urbanísticas fueron el establecimiento de tugurios, ocupas, inseguridad, insalubridad, imagen negativa del barrio y un éxodo masivo de los habitantes.

Diversas iniciativas locales intentaron aportar soluciones a la nueva situación generada por el abandono de la zona, pero no llegaron a surtir efecto, debido a la magnitud de los problemas generados. El ayuntamiento se dio cuenta de que para llevar a cabo el objetivo de regeneración del barrio debía contar, además de con un buen plan de rehabilitación urbana, con entes públicos y privados capaces de garantizar su realización.

La reflexión sobre la reconstrucción de la zanja comenzó en 1992, y concluyó en el esbozo de tres planes particulares de acondicionamiento del territorio afectado: el plan Sainte Marie, el plan Bonnevie y el plan Etangs Noirs. Los tres incluían en sus previsiones los inmuebles afectados así como los terrenos no construidos. Se 
vio la necesidad de elaborar un proyecto global de reconstrucción de la zanja del metro, cuyo enfoque global pretendía dos objetivos: restablecer la confianza en este distrito, afirmando claramente la voluntad de las autoridades municipales; y conseguir una masa crítica de construcciones que aportara credibilidad a la operación.

\section{El plan}

El proyecto Rive Gauche es un esfuerzo realizado por entidades públicas y privadas, cuyo fin es recuperar la calidad de vida de los habitantes de Molenbeek. Los grandes principios del acondicionamiento comprendido entre el Quai des Charbonnages y la Place des Etangs Noirs son los siguientes: dar prioridad a las viviendas, desarrollar diversas actividades mixtas frente al canal, restaurar un espacio público que pueda considerarse de calidad y reducir la circulación de tráfico rodado. El objetivo de la operación consiste en la construcción de 450 nuevas viviendas en una superficie de $45.000 \mathrm{~m}^{2}$, de los que $12.000 \mathrm{~m}^{2}$ se destinarían a comercios y $6.000 \mathrm{~m}^{2}$ a oficinas.

El proyecto de la Rive Gauche se basa en los siguientes principios: diversidad, espacio público, equipamientos y montaje integrado. Uno de los objetivos principales del proyecto es mantener la diversidad de funciones de una forma voluntaria: las empresas se instalan en los niveles inferiores de los inmuebles que se van a construir o rehabilitar; los niveles intermedios están destinados a pequeñas superficies de oficinas, mientras que las viviendas van ubicadas en los pisos superiores. El proyecto reconoce la importancia capital que ostenta la calidad en la ordenación del espacio público. La rehabilitación y creación de calles y plazas arboladas y peatonales es un objetivo prioritario. La circulación de vehículos, por tanto, queda relegada a los grandes ejes periféricos.

La rehabilitación del barrio debe apoyarse también en la realización de nuevos equipamientos públicos y la modernización de los ya existentes en la zona. Una nueva comisaría de policía y un nuevo polideportivo serán los primeros equipamientos en dar vida al distrito. Además, una pasarela peatonal conectará Molenbeek con el centro histórico de la ciudad. Entre los logros más importantes del proyecto se encuentran la calidad de los espacios públicos, el reacondicionamiento de las orillas del canal mediante su transformación en un paseo verde en el que se puedan implantar pequeñas empresas, y el precio competitivo de las viviendas en venta y los espacios destinados a actividades económicas (Figura 10).

\section{El resultado}

Desde 1992 y hasta el año 2010, en Molenbeek se han contabilizado 24 proyectos de edificación con un total de 639 viviendas construidas. La agencia encargada de su gestión ha sido la SDRB (Société de Développement Régional de Bruxelles), cuya misión consiste, por una parte, en proporcionar viviendas asequibles a la clase media; y por otra, en facilitar la implantación de empresas y generar empleo en el área. La inversión total de los 24 proyectos asciende a 50.592.578,10 euros. De entre las empresas instaladas en Molenbeek, cabría destacar L"Union International des Transports Publics (UITP). En las siguientes imágenes (Figura 12) se muestra un ejemplo de la evolución del barrio. 
FIgura io | Molenbeek. Plano del proyecto de rehabilitación Rive Gauche

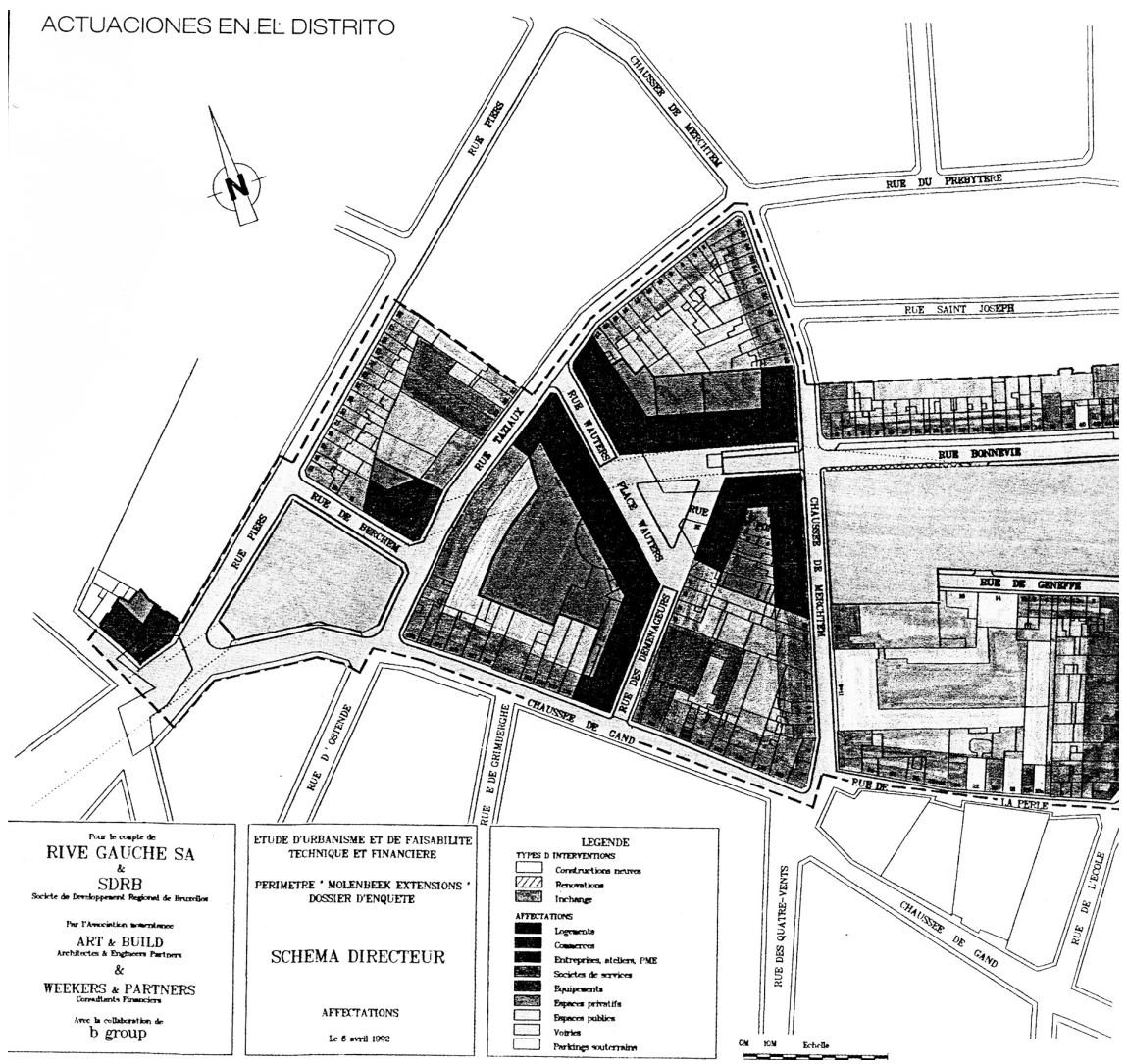

FUENTE urbanismo (REVISTA DEL COLEgIO OFICIAL DE ARQUiTECTOS DE MADRID, COAM), 27 (I996), P. 58

FIGURA I I | Molenbeek

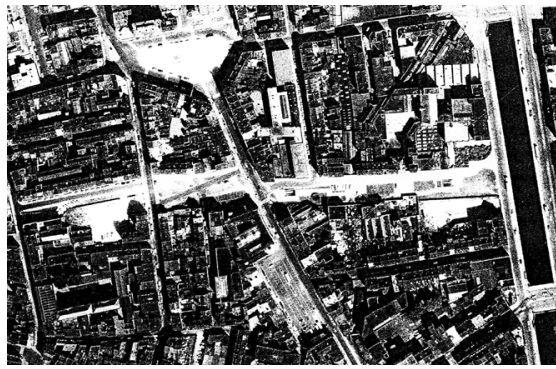

FUENTE Urbanismo (REVISTA DEL COLEGIO OFICIAL DE ARQUITECTOS DE MADRID, COAM), 27 (1996)

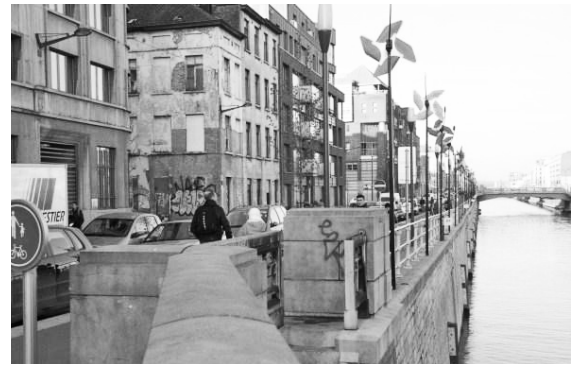

HTTP://WWW.BRUPLUS.IRISNET.BE/EN/CONTENT/ MOLENBEEK-METROPOLITAN-CULTURE-2O I 4 


\section{Mouraria. Lisboa \\ El barrio}

La rehabilitación urbana del barrio de la Mouraria en Lisboa se concibió como una intervención piloto que el ayuntamiento de Lisboa pretendía extender a todas las zonas históricas de la ciudad. La estructura física del barrio responde a un trazado medieval de inspiración musulmana, ya que su origen se remonta a la reconquista cristiana, cuando los moros fueron expulsados fuera de las murallas de la ciudad. La primitiva estructura viaria se ha mantenido hasta nuestros días debido a que se libró de los efectos del terremoto de 1755 y no ha sido objeto de grandes actuaciones.

En un proceso lento y constante de degradación urbana, los edificios han ido sufriendo alteraciones por obras realizadas sin ningún cuidado técnico, como el aumento del número de plantas. Las situaciones de ruina inminente debidas a la falta de mantenimiento periódico se han ido sucediendo con la sobreocupación de los hogares y la escasa implantación de actividades económicas. Alrededor del 50\% de los edificios se encuentra en muy mal estado de conservación y unos 70 edificios tienen daños estructurales. La marginalización social, funcional y física, por lo expuesto anteriormente, resulta evidente. Para la recuperación de la zona se creó el Gabinete Técnico de la Mouraria, perteneciente al Programa de Rehabilitación Urbana del Centro Histórico de Lisboa.

El Programa considera un objetivo primordial la creación de condiciones para la permanencia de la población que reside y trabaja en la Mouraria. Para ello se pretende obtener unos niveles mínimos de salubridad en las viviendas, así como la creación de equipamientos colectivos esenciales para los habitantes. Los principios orientadores de la acción del Gabinete Técnico de la Mouraria (GTM) son la protección activa del patrimonio arquitectónico y la cualificación del tejido social y económico.

\section{El plan}

Se procedió a la elaboración de un plan con cuatro objetivos: la protección activa del patrimonio, el fomento y desarrollo del tejido social y económico, la protección de usos urbanos tradicionales y la definición de las condiciones de seguridad. Para la protección del patrimonio se realizó un estudio del tipo de materiales y acabados exteriores, así como de los condicionantes urbanísticos existentes: alineaciones, tipología edificatoria, número de plantas, parcelación urbana y espacios libres. El GTM ha adquirido los inmuebles irrecuperables necesitados de reconstrucción, así como los terrenos destinados a espacios libres, equipamientos o edificios de realojo. La recuperación de inmuebles se basa en tres áreas de actuación: la recuperación de edificios propiedad del municipio, la recuperación de edificios particulares a través de ejecución subsidiaria y la ayuda a la recuperación de inmuebles particulares. Los realojos abarcan cuatro áreas de intervención: la recuperación de viviendas para realojo provisional, la construcción de nuevos edificios para alojamiento definitivo, las ayudas financieras al realojo y las indemnizaciones. 
FIgURA I 2 | Plano especial de salvaguarda: equipamiento

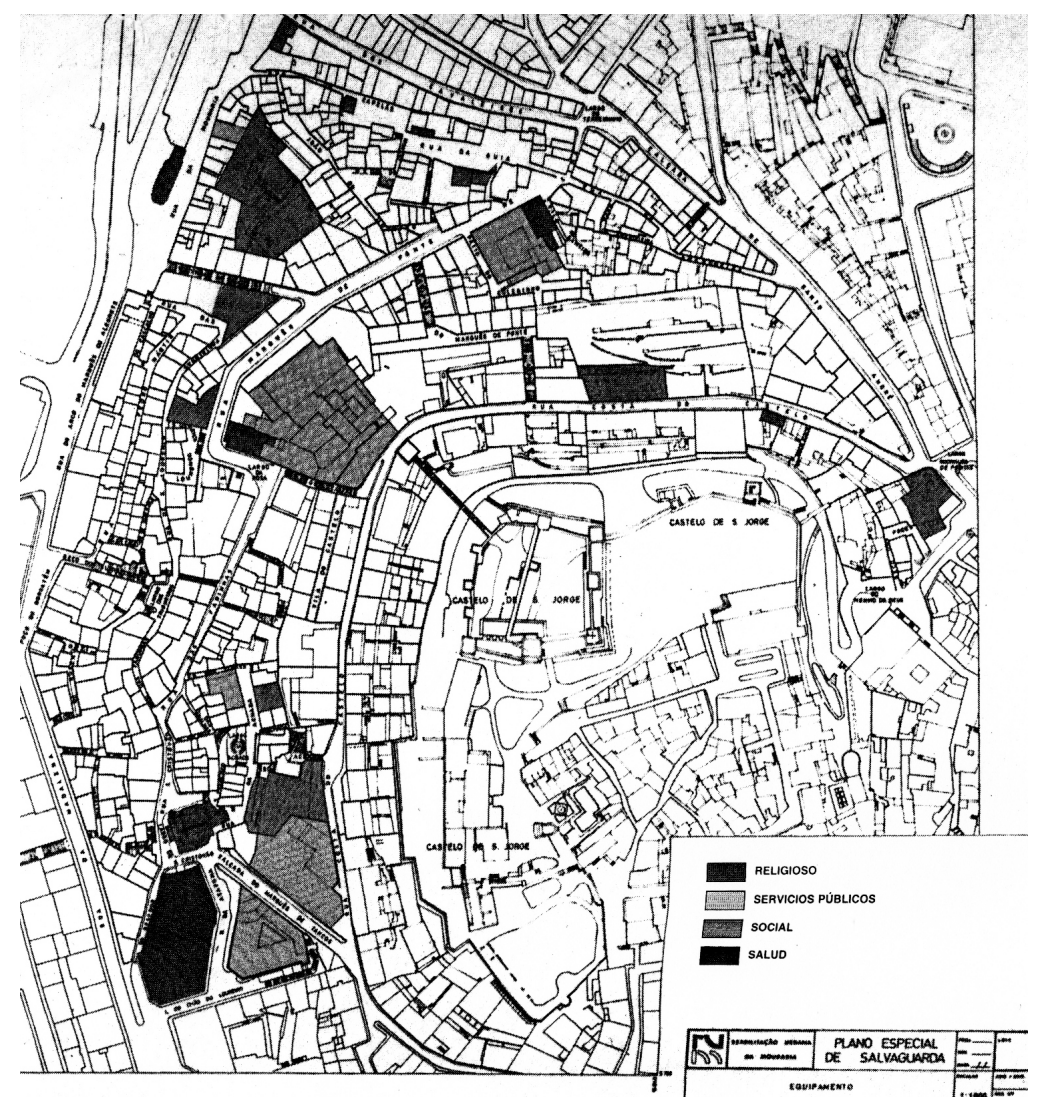

FUENTE J. ROCA CALDERA, rehabilitación urbana. análisis comparado de algunos países de la unión europea (1995), P. I 40

Con el plan, se pretende construir equipamientos colectivos de características diferentes, destinados tanto a la población residente como a la población en general (Figura 12). La intervención en los espacios públicos se basa en la actuación en los jardines y zonas verdes, viario y plazas públicas, y en las escaleras y pasos peatonales. La intervención en infraestructuras urbanas consiste en la pavimentación del viario, la remodelación del alcantarillado, la remodelación de los servicios públicos y la creación de una red de protección de incendios.

Como medida legislativa en el ámbito urbanístico, se procedió a la declaración de un Área Crítica mediante la cual se intentó eliminar las intenciones especulativas de muchos propietarios. Como medida económica se creó el Programa RECRIA (Regime Especial de Comparticipação na Recuperação de Imóveis Arrendados), un instrumento creado por el Gobierno de la nación, de financiación muy importante para la recuperación de edificios. El decreto iba destinado a apoyar a fondo perdido a los propietarios y ayuntamientos en la realización de las obras de edificios arrendados. Mediante el programa de desterciarización se pretende reinstalar las 
actividades nocivas para la seguridad y medioambiente en otros lugares, a fin de que no se pierdan puestos de trabajo.

Como medidas sociales, se aprobó un programa que proporcionaba completas garantías a los habitantes del barrio durante todo el proceso de desalojo, realojo provisional y alojamiento definitivo. Asimismo, se creó un Programa de Integración Social de las Poblaciones, con la participación de las fuerzas vivas del barrio. La experiencia de la rehabilitación del barrio de la Mouraria pretendió ser el punto de partida para la mejora de todo el conjunto histórico de la ciudad de Lisboa.

\section{El resultado}

El proceso de rehabilitación de la Mouraria se ha ido desarrollando de una forma pausada pero constante. En la actualidad se está ejecutando un plan de intervención, que actúa principalmente sobre el eje delimitado por las plazas Adelino Amaro da Costa y do Intendente. Dos equipamientos sociales, un edificio multifuncional, la rehabilitación de edificios de viviendas y una iglesia, y la mejora del espacio público -la plaza Martim Moniz y un parque- forman parte de un conjunto de actuaciones cuya inversión total asciende a 7.657.964 euros. En las siguientes imágenes (Figura 13) se muestra un ejemplo de la evolución del lugar.

\section{FIGURA I 3 | Mouraria}

\section{Antes de la rehabilitación del barrio}

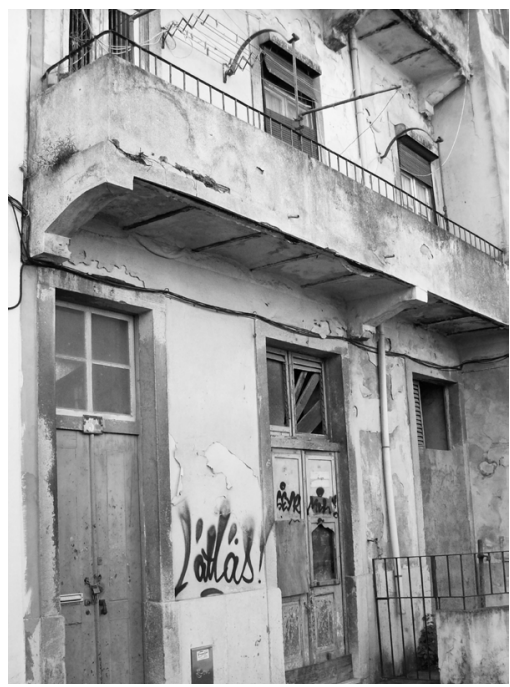

FUENTE HTTP://PEDRASI3.WORDPRESS.COM/ $20 I_{3} / 0_{4} / 05 / C A R T A-D E-L I S B O A-I I /$

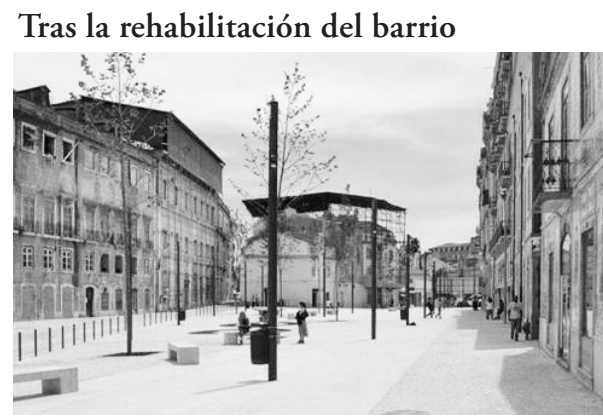

FUENTE HTTP://WWW.AIMOURARIA.CM-LISBOA. PT/HA-VIDA-NA-MOURARIA.HTML 


\section{Lavapiés. Madrid \\ El barrio}

Lavapiés se ubica al sur del núcleo originario de la ciudad de Madrid. Su traza, ya definida en el siglo XVII, no ha conocido mejoras relevantes, a excepción de algunos espacios públicos ocupados anteriormente por edificios institucionales. Desde el siglo Xvir, la mitad sur del barrio formaba parte de los arrabales de la ciudad donde se concentraban las actividades consideradas peligrosas. En la zona residía población trabajadora y de escasos recursos, y otras actividades marginales. Las edificaciones unifamiliares de una o dos plantas que contaban con amplios espacios traseros fueron dejando paso a un apretado caserío de edificios de habitación colectiva con miserables patios de luces.

En la actualidad hay tres universos demográficos que conviven en el barrio con cierta autonomía. Por una parte, se encuentra una población envejecida cuyos descendientes abandonaron el barrio en busca de otras zonas de la ciudad. La soledad y unas pensiones mínimas cubren con dificultad las necesidades de una población que se extingue silenciosamente y con escasas comodidades. Otro grupo está conformado por gente joven en torno a los treinta ańos, de alquiler y con una renta mayor. Es un grupo en tránsito que apenas reside unos cuatro años en el barrio. Por último, encontramos una población inmigrante que se ha disparado en los últimos años.

El barrio, por tanto, se caracteriza por una gran diversidad debido a las numerosas etnias y culturas de Europa, Asia, África y América; y por otro lado, por una fuerte inestabilidad debida a la precariedad del empleo, los sueldos bajos y la falta de población infantil y grupos familiares.

Lavapiés tiene el parque de viviendas más pequeñas de toda la ciudad de Madrid y posiblemente las más deterioradas. La envoltura digna que conforman las modestas fachadas del barrio oculta un tortuoso espacio interior caracterizado por la infravivienda. En las primeras crujías exteriores se ubican las mejores viviendas del barrio, pero tras ellas se esconden viviendas mínimas ventiladas e iluminadas por patios interiores, en cada una de las cuales se hacinan una o varias familias de inmigrantes (Figura 14).

\section{FIgURA I4 | Tipologías de viviendas en las manzanas de Lavapiés}
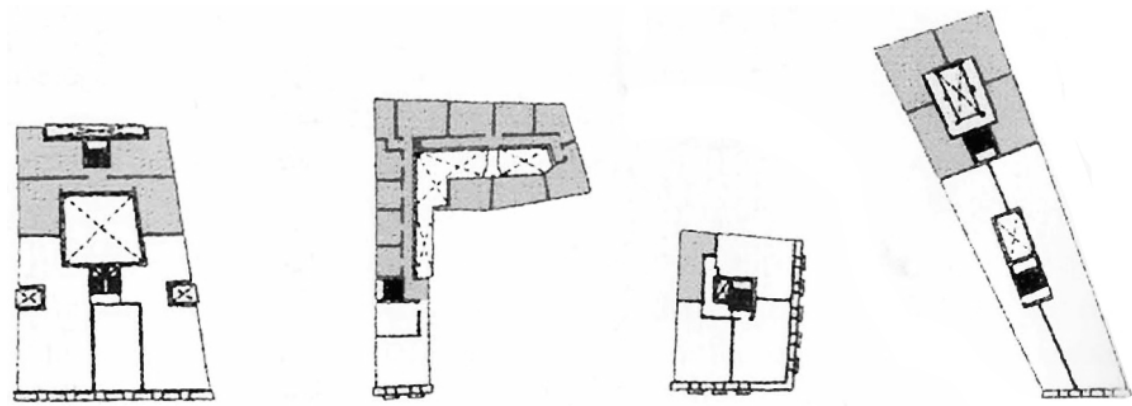

FUENTE J. BARRAChINA SALA ET AL., ciudades históricas ante el siglo xxi (2004), P. I I 8 
En la actualidad existen muchas viviendas vacías a expensas de las futuras actuaciones urbanísticas sobre la zona. Los precios han aumentado de manera imparable, derivado de concretas intervenciones municipales en materia de nuevos equipamientos.

\section{El plan}

Lavapiés fue declarada un Área de Rehabilitación Preferente debido a su evidente proceso de degradación. Esta política de intervención pretende mejorar la calidad de vida, regenerar el tejido social e impulsar la economía. Para ello, la solución más efectiva sería, quizá, expropiarlo todo y mantener la envoltura edificatoria que contara con una cierta calidad, vaciando los centros podridos. Sin embargo, las dificultades que conllevarían los costes económicos y políticos de una actuación de tal envergadura han derivado en otro tipo de actuaciones.

El área de rehabilitación preferente se legitima en una serie de principios organizados según su naturaleza socioeconómica, urbanística y arquitectónica. La recalificación urbanística implica la renovación de las infraestructuras, la regulación del tráfico y la mejora de los equipamientos.

La mejora arquitectónica se ocupa de alterar la física residencial, progresando en la calidad de los alojamientos. Un planeamiento especial cataloga las partes de los edificios que se protegen, como las fachadas, y delimita, de madera indicativa, los patios de manzana aireando el conglomerado existente. La Empresa Municipal de la Vivienda se encarga de coordinar el amplio programa de acciones mediante la creación de una comisión mixta de trabajo para asegurar la colaboración entre la Concejalía de la Vivienda y la Dirección General de Arquitectura y Vivienda de la Comunidad de Madrid.

\section{El resultado}

Cerca de 10.000 viviendas distribuidas en 500 edificios han sido intervenidas desde que fuera declarada el Área de Rehabilitación. La inversión total públicoprivada asciende a 145,20 millones de euros. Espacios urbanos, como el parque Casino de la Reina o la plaza de Agustín Lara, y equipamientos, como el edificio de las Escuelas Pías o el Mercado de San Fernando, son ejemplos de las actuaciones realizadas hasta la fecha. En las siguientes imágenes (Figura 15) se muestra un ejemplo de la evolución de Lavapiés. 
FIGURA I 5 | Lavapiés

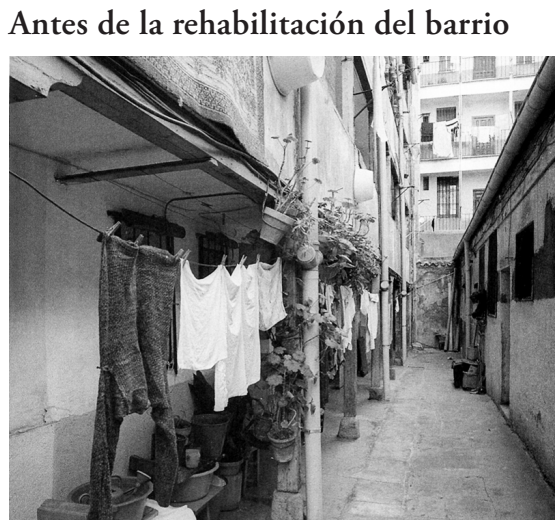

Fuente "Una "Corrala” (Desaparecida) EN LAVAPIÉS-EMBAJADORES, MADRID" urban idade 46 (23 SEPT. 2013). HTTP://URBANCIDADES.WORDPRESS.COM/ ?S=LAVAPI $\%$ C $3 \%$ A $9 S$
Tras la rehabilitación del barrio

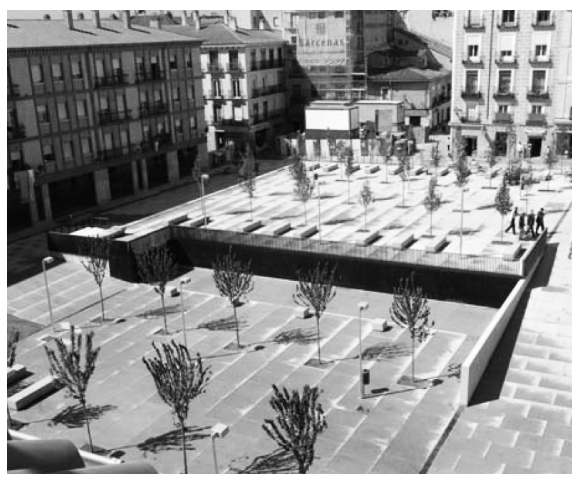

FUENTE “LA REHABILITACIÓN DE LAVAPIÉs”, es por madrid (4 NOV. 2008). HTTP://WwW. ESPORMADRID. ES/2008/I I/LAREHABILITACIN-DE LAVAPIS.HTML

\section{Reflexiones}

Mediante la descripción de los diversos ejemplos de rehabilitación urbana se ha puesto en evidencia la creciente importancia que, a partir de la segunda mitad del pasado siglo xx, ha tenido la rehabilitación urbana en Europa. Cada vez son más las ciudades que intentan poner los medios que cuentan a su disposición para curar esa herida que va haciéndose más y más profunda con el tiempo. Asimismo, vemos cómo los conceptos que se han ido enumerando en la introducción se han repetido constantemente en los planes de rehabilitación estudiados.

Kreuzberg, con sus doce principios de renovación urbana, asimila el tratamiento del espacio público y la diversidad urbana desarrollados por Jane Jacobs y Richard Rogers. Las intervenciones puntuales equivalen al preciso ejercicio de acupuntura de Jaime Lerner. Kreuzberg, hoy, a pie de calle, se presenta al visitante como un barrio renovado con nueva energía conseguida tras ańos de luchas por mantener viva su propia esencia. Proyectos emblemáticos, como el popular edificio de Álvaro Siza en el bloque 21, denominado Bonjour Tristesse, han contribuido a potenciar la imagen del barrio entre los habitantes de Berlín.

El barrio de Bolonia estudiado cuenta con la idiosincrasia de pertenecer al centro histórico de la ciudad, con la problemática particular que eso comporta. El peligro de intervenir en un centro histórico degradado radica en la posibilidad de transformarlo en el bello cadáver embalsamado con técnicas de conservación, que nos presentaba Gildo Seisdedos. Turistas y estudiantes conforman los grupos principales que aportan un gran dinamismo al centro histórico. 
En Le Marais, los cafés, las tiendas de diseño y sus fachadas renovadas esconden un proceso de gentrificación por el cual algunos de sus habitantes han sido paulatinamente sustituidos por otros con un nivel económico mayor. Debido a su estratégica ubicación dentro de la ciudad de París, la rehabilitación ha fomentado una constante presencia de turistas.

Ferner y Balat, a diferencia de los casos anteriores, se ubica en la periferia de la ciudad de Estambul. Los resultados no son tan evidentes, ya que todavía permanecen a la vista determinadas zonas con bolsas de degradación urbana que esperan pacientemente que les llegue su turno para la rehabilitación.

En Molenbeek se constata la evidencia del planteamiento de Oriol Bohigas contra los edificios monofuncionales y su férrea defensa de la mezcla de funciones diversas. Este desarrollo permite en la actualidad una presencia prácticamente constante de personas a lo largo de buena parte del día.

La Mouraria continúa con su lento pero constante proceso de rehabilitación. Una de las principales ventajas es que no se está expulsando a la población tradicional del barrio, que se mantiene fielmente, tal y como establecía Grossman en su alegato a favor de la vuelta al barrio.

Lavapiés, por último, se nos presenta en la actualidad con una cara lavada y una mejora considerable de la calidad del espacio público, por las actuaciones antes mencionadas. Sin embargo, y debido a las enormes dificultades de gestión y presupuestarias que conllevaría su modificación, tras las fachadas renovadas de sus edificios se siguen manteniendo tipologías de infraviviendas iluminadas por minúsculos patios de luces.

Zonas degradadas en nuestras ciudades siempre ha habido. La novedad puede estar en la forma de degradación: guetos, colectivos marginados de bajos ingresos junto a una brutal especulación urbanística, provocan que una determinada zona, bien planeada en su día, acabe en un profundo caos.

Hay una serie de conceptos que destacan en los planes expuestos: la diversidad social, la calidad de los espacios públicos y la salvaguarda. Si no existe diversidad social en una determinada zona, se produce un gueto, lo cual provoca la creación de una barrera invisible que la separa del resto de la ciudad. La diversidad, por tanto, crea riqueza y evita la marginación.

Para que una parte de una ciudad recupere la energía perdida, debe tener espacios públicos de calidad. El barrio no es un sitio de paso que tiene que atravesar la población para acceder a su domicilio o a su trabajo, que normalmente suele estar alejado de la residencia habitual. El barrio debe tratarse de un punto de encuentro, de un lugar en el que conectar y establecer vínculos. La presión popular provoca que la conservación prevalezca sobre otras medidas de renovación urbana.

La fuerza expansiva que ha provocado el inmenso crecimiento de las ciudades hacia la periferia ha ido acompañada por otra fuerza que ha profundizado el deterioro de algunas zonas del corazón urbano. Resulta necesario, por tanto, rehabilitar el centro para recuperar la ciudad herida. 


\section{Referencias bibliográficas}

AA.VV. (1985). AV Monografías 1. Berlín, IBA "87. La Exposición Internacional de Arquitectura (1) I-III 1985 .

Álvarez Mora, A. \& Roch, F. (1980). Los centros urbanos. Madrid: Nuestra Cultura.

Ascher, F. (2001). Les nouveaux principes de l"urbanisme. La fin des villes n"est à l"ordre du jour. La Tour d"Aigues: Édition de l"Aube. [Traducción castellano: Los nuevos principios del urbanismo. Madrid: Alianza Editorial, 2004].

Augé, M. (1993). Los “no lugares", espacios del anonimato. Una antropología de la sobremodernidad. Barcelona: Gedisa.

Barrachina Sala, J., Bellodi, N., Birulés, J. M., Calduch Cervera, J., Casar Pinazo, J. I., Chaudoir, Ph., Dalda Escudero, J. L., Dolç I Soriano, C. (...) \& Jiménez Alcañiz, C. (2004). Ciudades históricas ante el siglo xxi. Valencia: Ícaro.

Benevolo, L. (1979). Le origini dell"urbanistica moderna. Roma y Bari: Gius. Laterza \& Figli, SpA. [Traducción castellano: Orígenes del urbanismo moderno. Madrid: Celeste, 1994].

Benevolo, L. (1960). Storia dell"architettura moderna. Roma y Bari: Gius. Laterza \& Figli, SpA. [Traducción castellano: Historia de la arquitectura moderna ( $8^{\mathrm{a}} \mathrm{ed}$.). Barcelona: Gustavo Gili, 2002].

Bohigas, O. (2004). Contra la incontinencia urbana. Reconsideración moral de la arquitectura y la ciudad. Barcelona: Electa.

Bravo, L. (2009). Area conservation as socialist standard-bearer: a plan for the historical centre of Bologna in 1969. Docomomo E-Proceedings 2, 44-53. En http://www.fredmussat. fr/e-proceedings2_dec09/Docomomo\%20E-proceedings2.pdf

Calabi, D. (2000). Storia dell"urbanistica europea. Questioni, strumenti, casi esempiari. Turín: Paravia Bruno Mondadori.

Clerval, A. (2008). Les anciennes cours réhabilitées des faubourgs: une forme de gentrification à Paris. Espaces et sociétés, 1-2(132-133), 91-106. doi: 10.3917/esp.132.0091

Corbusier, Le. (1957). La Charte d"Athènes. París: Fondation Le Corbusier y Èditions de Minuit. [Traducción castellano: Le Corbusier. Principios de Urbanismo. Barcelona: Ariel, 1989].

Forßmann, J. (1990). La renovación cautelosa de Berlín-Kreuzberg. Ciudad y Territorio, (85), $67-81$

Glaeser, E. (2012). Triumph of the City. Londres: Penguin Books.

Grossman,L.J.(2008). Volveralbarrio.Arquitextos, posted 10 abril 2008. En https://distritoactivo. wordpress.com/2008/04/10/textos_arquitextos_grossman_02/\#more-51. También en Arquitextos. Buenos Aires: Ediciones Infinito, 2003.

Hämer, H. W. (1985). Entrevista con Hardt Waltherr Hämer (Redacción AV Mongrafías). AV Monografias de Arquitectura y Vivienda. I. berlín iba "87 La Exposición Internacional de Arquitectura (1), pp. 70-71.

Jacobs, J. (1961). The death and life of great American cities. Nueva York: Random House. [Traducción castellano: Muerte y vida de las grandes ciudades. Madrid: Capitán Swing Libros, S.L., 2011].

Kennedy, D. \& Kennedy, M. (1974). The Inner City. Londres. Paul Elek Books. [Traducción castellano: La ciudad interior. Barcelona: Gustavo Gili, 1978].

Lerner, J. (2005). Acupuntura urbana. Barcelona: Jaime Lerner. 
Lynch, K. (1960). The image of the city. Cambridge, MA/Londres: The mIT Press. [Traducción castellano: La imagen de la ciudad. Barcelona: Gustavo Gili, 1998].

Morris, A. E. J. (1979). History of urban form. Before the industrial revolutions. (2a ed.). Longman Group uk Ltd. [Open Library]. [Traducción castellano: Historia de la forma urbana desde sus origenes hasta la Revolución Industrial. Barcelona: Gustavo Gili, 1984].

Muñoz, F. (2008). Urbanalización. Paisajes comunes, lugares globales. Barcelona: Gustavo Gili.

Panerai, P. \& Mangin, D. (1999). Project urbain. Marsella: Parenthèse. [Traducción castellano: Proyectar la ciudad. Madrid: Celeste, 2002].

Roca Caldera, J. (1995). Rehabilitación urbana. Análisis comparado de algunos paises de la Unión Europea (Alemania, Bélgica, Dinamarca, Francia, Italia y Portugal). Madrid: Ministerio de Obras Públicas, Transporte y Medio Ambiente (мортмA).

Rogers, R. (2012). Ciudades para un pequeño planeta. Barcelona: Gustavo Gili.

Sánchez, C. (2010). El inevitable peaje de transformar un barrio degradado en un barrio de moda: Prenzlauer Berg y Bolonia. Urbanismo en serie [blog, 10 nov. 2010]. En http:// urbanismoenserie.blogspot.com/2010/11/el-inevitable-peaje-de-transformar-un.html

Seisdedos, G. (2007). Cómo gestionar las ciudades del siglo xxi. Del city marketing al urban management. Madrid: Prentice Hall. [Texto "Cómo gestionar las ciudades del siglo XxI (01)", en Distrito Activo (Concurso de ideas), blog de Arquitectos Sen Fronteiras, posted 15 abril 2008. En https://distritoactivo.wordpress.com/2008/04/15/textos_comogestionar-las-ciudades-del-siglo-xxi_gildo-seisdedos_01/

Serra, C. (2005, julio 31). Jaime Lerner propone mejorar la ciudad mediante la “acupuntura”, El País, 31 julio 2005, s/p. En http://elpais.com/diario/2005/07/31/ cultura/1122760804_850215.html

Tuncer, M. (2006). From Kreuzberg to Fener-Balat. "12 principles of conservative urban renewal”. 42 $2^{\text {nd }}$ ISoCaRP Congress 2006. En http://www.isocarp.net/Data/case_ studies/820.pdf

Urban Idade 46 - Memoria de las redes urbanas [blog de E. Fidel]. En http://urbancidades. wordpress.com/

urbed/ten Group. (2008). Learning from Berlin. Housing renewal and sustainable development. Londres: Autor. En http://www.urbed.com/sites/default/files/get_binary_doc_ object_7.pdf

Vaes, J. (1996). El proyecto Rive Gauche. Reconstrucción de Molenbeek, un antiguo distrito del centro de Bruselas perjudicado por la construcción del metro. Urbanismo. Revista del Colegio Oficial de Arquitectos de Madrid (coam), (27), 56-61. 
